\title{
SRI LANKAN GRADUATES' PERSPECTIVES ON VOCATIONAL EDUCATION AND POST-STUDY EMPLOYMENT
}

\author{
Bradley Hannigan and Dilhan Athapaththu
}

\section{INTRODUCTION}

This research explores Sri Lankan graduate perspectives on vocational education and experiences of work readiness. The creation of Te Pükenga - New Zealand Institute of Skills and Technology and subsequent developments in the vocational education space in Aotearoa New Zealand hold the promise of new ways of envisioning how the vocational education curriculum can work. The participants in the research were 14 Sri Lankan graduates of a postgraduate applied management programme in one Te Pükenga - New Zealand Institute of Skills and Technology subsidiary. Participants were interviewed and provided insights into their experiences, as well as providing suggestions for the ongoing development of vocational education provision in Aotearoa New Zealand.

The recent and ongoing merger of Aotearoa New Zealand's 16 polytechnics and the integration of industry training organisations into one organisation has been in the news since the Review of Vocational Education (RoVE) was announced for consultation at the beginning of 2019. According to the Ministry of Education (2019), "the world of work is changing significantly, and vocational education needs to adapt to stay ahead of these changes" (p. I). Vocational education is career-focused, with the aim of supporting learner mobility into work: "Vocational education and training gives you skills that can lead to an exciting new career direction," where learners are challenged to "choose a vocation for a better future" (careers.govt.nz, 202I). This article explores the experiences of a specific group of students who were enrolled in, and graduated from, vocational education and training in Aotearoa New Zealand: international students - in particular, Sri Lankan students studying applied business management.

The question used for this research was "What are the experiences of Sri Lankan students transitioning from vocational education to work?" The aim of this research was two-fold: to explore experiences of this particular group of students, as well as giving voice to the experiences of Sri Lankan graduates. The approach taken is inductive and exploratory. This approach was selected to ensure that data collection and interpretation could proceed unhindered by a theoretical framework. The value of this research lies in providing graduate experiences as a reflection piece for vocational education and educationalists in Aotearoa New Zealand.

The marketing message of the vocational education industry raises a realisable hope that offers the promise of a better future, not only for individuals but for the community and society at large (Tertiary Education Commission, 202I). However, is this the case for all graduates? This article offers insights into Sri Lankan graduate experiences of transitioning into the job market after graduation. In 2019 there were 226,270 students enrolled in vocational education and training in this country (Education Counts, 2021). Of this number, 16 percent were ethnicities other than European, Māori and Pacific Peoples (Education Counts, 2021). The data includes not only international students in general, but also Sri Lankan students in vocational institutions. 
International students are people who leave their homelands for higher education (Morris-Lange \& Brands, 2015). Research has shown that a large proportion of those students stay in their host country post-training and find meaningful employment there (Bryła, 2019; Wu \& Wilkes, 2017). While international students may study in a country for multiple reasons including gaining international exposure (Beech, 2018) and personal learning (Mucsi et al., 2019), post-study employment is a major motivation (Le \& LaCost, 2017).

While research on international students' vocational experiences post-study in Aotearoa New Zealand is relatively scarce, some similar studies to this research project have been carried out. Dyer and Lu (20I0) reported the experiences of ten Chinese students and their post-study transition to work. Although participants were not enrolled in vocational education per se, this study showed that holding a New Zealand qualification and having English-language skills, peer and work networks built up through study were essential to finding work post-study for this group. Again in 2010, The New Zealand Department of Labour published its Life After Study report (Wilkinson et al., 2010), which found that 68 percent of former graduates who stayed in Aotearoa New Zealand found employment; that degree and post-degree qualifications were good predictors of post-study employment success; and that language proficiency and work readiness were central elements for successful employment.

Researchers have shown that many international students study abroad for more reasons than gaining a foreign qualification (Huang et al., 2014). Employability (Gribble et al., 2017), practicality (Eichhorst et al., 2015) and job-related experiences (Gautam et al., 2016) are all areas of concern for many international students. They are the clients of an education sector that has long been dependent on the contribution that international students make to the financial outcomes of tertiary institutions (Marshall, 2019). It is a benefit that therefore goes, or should go, two ways. New Zealand has been quick to leverage this situation: international student numbers doubled between 2007 and 2017 (Education Counts, 2020), with approximately 50 percent of doctoral candidates being international students (Burns \& Rajcan, 2019), and the income derived from international students in 2018 exceeding NZ\$5.I billion (Education New Zealand, 2020).

The New Zealand International Education Strategy/He Rautaki Mātauranga a Ao (Ministry of Education, 20l8) aims to deliver "an excellent education and student experience" including student satisfaction and "alumni outcome success" (p. 9). While the indicators of success in the strategy document all appear reasonable, for the most part they are educational and nationally strategic, avoiding employability as an outcome - except to say that students who choose to stay in Aotearoa New Zealand "are appropriately skilled and qualified" (Ministry of Education, 2018, p. 13). There is no indication of what "appropriately" means in this general context, or in a vocational education sense. The Te Pükenga - New Zealand Institute of Skills and Technology (2020) strategic priorities for internationalisation take this commitment into the vocational education space, with strategic objectives aiming to develop and deliver high-quality vocational education, including a commitment to consider ongoing programme and qualification development.

Since this research was carried out in early 2020 the COVID-19 pandemic has taken hold worldwide. Subsequent border closures have meant that the international student market has dried up, having a disastrous effect on tertiary education organisations in Aotearoa New Zealand (Blommerde, 2020; Kenny, 2020). In 2021 the country's borders opened to 1000 international students, only 135 of whom have so far arrived in the country, six months on from the announcement (Wiltshire, 2021). This situation may well provide organisations with the time thay need to rethink exactly what they are offering international students in terms of vocational education, and how courses and other offerings can not only best meet academic outcomes, but also the employment aspirations of those who enrol. This article adds the experiences and voices of a group of I 4 Sri Lankan graduates from one vocational education programme in Aotearoa New Zealand to the mix. 


\section{METHODOLOGY}

Data for this study was collected between 25 February and 16 March 2020 via semi-structured interviews. Ethical approval was obtained before the research commenced (NMIT2020-I). Participants were selected using the following criteria: they had come to Aotearoa New Zealand as Sri Lankan-born international tertiary-level students; they had gained a New Zealand tertiary qualification; they had completed their education at a vocational education institution; and they had gained (or were in the process of gaining) post-study employment in Aotearoa New Zealand. Given the exploratory nature of this research, we followed an inductive strategy whereby understandings are constructed from the data itself, rather than compared, contrasted or organised using an a priori theoretical framework. Inductive thematic analysis was used to organise the responses of participants and garner insight into their experiences. In reporting here, our aim is to let participants' words tell their story with as little interpretation as possible.

\section{FINDINGS AND ANALYSIS}

When asked about how their vocational education supported them to gain employment, two thirds of participants noted that they had gained good subject knowledge, but not the skills to be work-ready. This disappointment experienced by participants was the first theme of the research. One participant stated: "It gave me the whole background of, like, every subject. But I think those subjects were not really helpful to, like, adapt to a new environment or a new job." Reflecting on the need to be more strategic in selecting a programme of study, another participant stated:

I am strongly advising if someone wants to come to New Zealand, they have to go through the skill list first, and then they have to find a program which is [a] skill shortage in New Zealand, rather than finding a programme just to come to New Zealand.

Participants said that regardless of the qualification they had earned, they found it very difficult to get their foot in the door of prospective employers: "I applied [for] nearly, like, a thousand or two thousand jobs and was really fed up to apply for many jobs. The experience was really hard; I was really fed up of, like, applying for jobs." All but one participant said that finding work after their study was completed was a lot harder than they had thought it would be. One participant was thoroughly disillusioned: "Unfortunately, there were not any internships or job-related training opportunities for the qualification that I have completed."

Aside from these disappointments, a second theme extracted from the data was the value that participants placed on their study in terms of gaining a better understanding of Aotearoa New Zealand work cultures, and developing skills that could be applied to employment contexts. For example, one participant said: "I think you have to be open-minded and also understand those differences between work culture, respect different views. If you have a better understanding, it is easy to work in the New Zealand workforce." Another participant agreed, stating: "If you keep on thinking [about] what you did in Sri Lanka, it may be very difficult to adapt to [the] New Zealand work environment." In terms of the skills developed through their educational experience, one participant reflected that "I developed lots of managerial skills and [skills in] managing everything together." Participants reported they developed communication and analytic skills from their study that put them in good stead for obtaining future employment.

A third theme that arose from the interviews was what worked for participants when it came to finding employment. This theme encompassed both advice and reflection on personal experiences. All participants agreed that the networks and connections they made through their studies were the primary means of finding employment; one participant captured this theme nicely in this piece of advice: "Even while you are studying, you have to find out ways and avenues, especially making connections with the business environment, people, managers you know, 
make networks - without networking you wouldn't be able to find a job." Other participants talked about how a part-time job held while studying had led them to find full-time employment, advising students to think carefully about not only what they study, but also where they work while they are studying. One participant stated that they got "a part-time job which is exactly the same job that I do now in full time". Other participants claimed that it was the skills and experience that they brought with them to Aotearoa New Zealand that landed them a post: "My Sri Lanka experience also helped me a lot to secure this job." Who you know and what you have done were seen as key determinants in finding work post-study.

The final theme that emerged from the interviews was a willingness by participants to offer advice as to what could have been done differently to enhance their vocational education experience, particularly in the area of finding employment after graduation. Participants strongly advocated the need for more opportunities to engage with the local business community through their study; one participant stated: "I selected the workplace elective ... So it gave me a good idea to understand how New Zealand companies work." This participant used that experience and the connections made to quickly secure full-time work at the end of their study. Another participant was quite pointed in their advice: "The job market should interconnect with the studies. What I mean is, unfortunately, there were not any internships or job-related training opportunities for the qualification that I have completed." Another participant echoed this sentiment: "I think they can give more internships and experience focus training for international students," and another suggested: "At least have a strategy to support migrant students not only to complete their studies, but for things to support after their studies."

This radical idea that vocational education institutions have a responsibility beyond the provision of a programme of study was taken a step further by another participant: "Helping them to find a new job in New Zealand after they complete their studies would [be] beneficial for them, to find jobs easily and quite fast." Another went further and took aim at the wider context in which vocational education is provided: "If you're getting lots of international students into small cities, it's important to have the infrastructure built and to develop more jobs. So that students won't move out, they will stay here and look for work." This last point underlines that the transition from vocational education into employment can not only be unsettling and fraught with uncertainty but, conversely, could potentially be planned in advance as part of the course provision. This last proposition poses a particularly interesting problem for an education system that separates training from negotiating subsequent employment.

\section{DISCUSSION}

Similar to the research undertaken by Dau and Lu (2010), our research found that students gained linguistic and cultural capability and technical skills from their education experience. Dau and Lu (20I0) studied university students, whereas our research focused on graduates from a vocational institution. While it might be expected that those enrolled in vocational education would have higher expectations of employment post-study, given the organisation's name and function, both groups had similar expectations of employment at the conclusion of their study. Like Dau and Lu (20I0), our study found that participants voiced a mix of responses - disappointment, success and also hope. The benefits of vocational education outlined in our findings also resonate positively with Department of Labour research on the benefits of local education for international students (Wilkinson et al., 2010).

The experiences and hopes of Sri Lankan graduates outlined here highlight two particular opportunities for curriculum design in vocational education: providing opportunities to connect with local businesses through the curriculum itself, and encouraging a shift in the role of the institution towards supporting employment (after-sales service). This could be done through internships being built into the design of papers and the teaching and learning programme itself. Postgraduate study programmes in management and business are traditionally more academic than experiential in their design. To integrate an experiential component in terms of internship or a practicum 
scenario requires not only design changes to the structure of programmes, but also significant logistical investment in terms of managing these components. Furthermore, there may be further difficulties in terms of getting local businesses to welcome students, particularly in small centres where demand may quickly outstrip supply. That said, the call to support graduates into paid employment at the end of their study is perennial (Gribble et al., 2017; Le \& LaCost, 2017; Wilkinson et al., 2010).

The idea of including internships in vocational business studies programmes is not new and exists to some extent in multiple organisations. However, the idea that vocational education providers also have a responsibility to support graduates into work at the end of their study is more radical. It stretches the notion of vocational education from merely providing skills leading to exciting opportunities (Careers.govt.nz, 202I) towards an education system that really has skin in the game of supporting students into vocations. This is a shift from a curriculum premised on the hope of employment to one premised on the promise of employment. At present, this proposition seems outside the realms of what is possible, given the structure of tertiary education in Aotearoa New Zealand. However, for the participants in this research, the prospect of their education provider having a more active role in their subsequent employment was a distinct possibility. At a time when all the cards for vocational education have been 'thrown in the air,' this idea could well be put on the table.

Our research provides feedback from end users of vocational education just prior to the 2020 COVID- 19 lockdown. The respondents' views challenge vocational educators, particularly in subjects like business studies, where there is no clear progression into work (as opposed to trades, nursing and hospitality), to consider precisely what the vocational component of the education they are offering may be. If it does not end in a vocation, or provide experience that not only results in skills, but also connections in the field of management, then how does this differ from the theory-focused curriculum of universities? Furthermore, what are the challenges for tutors when it comes to not only being subject experts, but also experts in finding and maintaining workplace placements? Do vocational institutions need to include another department when it comes to placing and maintaining placements during a course of study, and securing employment opportunities post-study? The implications are many.

Our research gives reason to pause at a time when vocational education in Aotearoa New Zealand is being reconsidered. Structural changes in terms of the merger of 16 polytechnics into one nationwide Te Pükenga New Zealand Institute of Skills and Technology are only one part of the change. What the curriculum looks like for different subjects across the organisation is another. This particular shift opens the door to new thinking about vocational education when it comes to subjects like business studies. What is the vocational element that is being incorporated in the design? Is it a set of skills and practices that the student takes away with them to apply to future employment? Is it the provision of practical experience in businesses alongside the development of skills, integrated as part of the formal curriculum? Or do we go a step further and develop employment opportunities as a necessary outcome of vocational education and training in the business domain? Or a blend of all these approaches? Now may be the time to have this conversation for, as the feedback from these graduates shows, what counts as an excellent student experience and alumni outcome success (Ministry of Education, 20I8), and what counts as high-quality vocational education (Te Pükenga, 2020) are still contested and contestable terms. 
Bradley Hannigan is a principal academic at Nelson Marlborough Institute of Technology where he teaches research methods and international strategic planning and supervises research students. Bradley has research interests in pragmatic philosophy, critical education theory, and strategic and change management.

(D) https://orcid.org/0000-0003-2940-39|4

Dilhan Athapaththu was a student at Nelson Marlborough Institute of Technology where he completed his Master of Applied Management. In his home country of Sri Lanka, Dilhan held multiple senior management positions as well as being a trained lawyer. Currently he is an area manager at Seen Safety for the Asia-Pacific region.

\section{REFERENCES}

Beech, S. E. (20/8). Adapting to change in the higher education system: International student mobility as a migration industry. Journal of Ethnic and Migration Studies, 44(4), 610-625.

Blommerde, C. (2020, July 3). Uni enrolments spiral down as international students numbers plummet. Stuff. https://www.stuff. co.nz/national/education//2195303//uni-enrolments-spiral-down-as-international-students-numbers-plummet?rm=a

Bryła, P. (2019). International student mobility and subsequent migration: The case of Poland. Studies in Higher Education, 44(8), $1386-1399$.

Burns, E., \& Rajcan, A. (2019). Publishing outputs of sociology PhD candidates at New Zealand universities, 2013-2017. New Zealand Sociology, 34(I), 5I-74.

Careers.govt.nz. (2021). Vocational education and training. https://www.careers.govt.nz/plan-your-career/get-ideas-for-yourcareer/vocation-nation/

Dyer, S., \& Lu, F. (20I0). Chinese-born international students' transition experiences from study to work in New Zealand. Australian Journal of Career Development, 19(2), 23-31.

Education Counts (2020). Tertiary education enrolments by international students. https://www.educationcounts.govt.nz/__data/ assets/pdf_file/0020/6437/Tertiary-education-enrolments-by-international-students-indicator.pdf

Education Counts. (202I). Participation in vocational education and training programmes. https://www.educationcounts.govt.nz/ statistics/vocational-education-and-training

Education New Zealand (2020). Annual report 2018-2020. https://enz.govt.nz/assets/Uploads/ENZ-Annual-Report-20I8-2020. pdf

Eichhorst, W., Rodríguez-Planas, N., Schmidl, R., \& Zimmermann, K. F. (2015). A road map to vocational education and training in industrialised countries. ILR Review, 68(2), 314-337.

Gautam, C., Lowery, C. L., Mays, C., \& Durant, D. (2016). Challenges for global learners: A qualitative study of the concerns and difficulties of international students. Journal of International Students, 6(2), 50I-526.

Gribble, C., Rahimi, M., \& Blackmore, J. (2017). International students and post-study employment: The impact of university and host community engagement on the employment outcomes of international students in Australia. In L. T. Tran, \& C. Gomez (Eds.), International student connectedness and identity: Transnational perspectives (pp. 15-39). Springer. https://doi. org/I0.1007/978-98I-10-260I-0_2

Huang, R., Turner, R., \& Chen, Q. (2014). Chinese international students' perspective and strategies in preparing for their future employability. Journal of Vocational Education \& Training, 66(2), 175-193.

Kenny, L. (2020, May 29). Almost half of Lincoln University's students from overseas, report says. Stuff. https://www.stuff.co.nz/ national/education//21652267/almost-half-of-lincoln-universitys-students-from-overseas-report-says? rm=a

Le, A. T., \& LaCost, B. Y. (2017). Vietnamese graduate international student repatriates: Reverse adjustment. Journal of International Students, 7(3), 449-466.

Marshall, S. (2019). Are New Zealand universities underperforming? An analysis of international enrolments in Australian and New Zealand universities. Compare: A Journal of Comparative and International Education, 49(3), 47I-488.

Ministry of Education. (2018). International education strategy/He rautaki mātauranga a ao 2018-2030. https:/lenz.govt.nz/assets/ Uploads/International-Education-Strategy-2018-2030.pdf

Ministry of Education. (2019). Reform of vocational education: Information for staff of institutes of technology and polytechnics (ITPs). https://conversation.education.govt.nz/assets/RoVE/ Infosheet-ITP-Staff-Reform-ofVocational-Education.pdf 
Morris-Lange, S., \& Brands, F. (2015). Train and retain. Career support for international students in Canada, Germany, the Netherlands and Sweden. The Expert Council of German Foundations on Integration and Migration.

Mucsi, A., Malota, E., \& Török, A. (2019). International student motivations and satisfaction with the study abroad program. In L. G. Chova, A. L. Martínez, \& I. C. Torres (Eds.), EDULEARNI9 (pp. 3175-3179). IATED Academy.

OECD. (2019). OECD economic surveys: New Zealand, 2019. OECD Publishing.

Te Pūkenga. (2020). Mobilising for internationalisation in a new world. https://xn--tepkenga-szb.ac.nz/news/category/News/ mobilising-for-internationalisation-in-a-new-world

Tertiary Education Commission. (202I). Reform of vocational education. https://www.tec.govt.nz/rove/reform-of-vocationaleducation/

Wilkinson, A., Merwood, P., \& Masgoret, A. (2010). Life after study: International students' settlement experiences in New Zealand. https://www.mbie.govt.nz/dmsdocument/2743-international-students-settlement-experiences-pdf

Wiltshire, L. (2021, June 19). Half a year after 1000 international students were allowed into NZ, just 135 have arrived. Stuff. https://www.stuff.co.nz/national/education/I25457652/half-a-year-after-1000-international-students-were-allowed-intonz-just-135-have-arrived

Wu, C., \& Wilkes, R. (2017). International students' post-graduation migration plans and the search for home. Geoforum, 80 , 123-132. 